\title{
PENGARUH PENDEKATAN MATEMATIKA REALISTIK TERHADAP PENINGKATAN KEMAMPUAN PEMAHAMAN KONSEP MATEMATIS SISWA
}

\author{
Azrina Purba \\ Prodi Pendidikan Matematika STKIP Pelita Bangsa Binjai \\ azrinapur@gmail.com
}

\begin{abstract}
The purpose of this study is to determine the effect of learning by using a realistic mathematical approach to the ability to understand students' mathematical concepts. This research is a quasi-experimental research. This research was conducted at MTs Islamiyah Medan. The research sample consisted of 50 students, 25 experimental class students, and 25 control class students obtained by cluster random sampling technique in class VII students. The results of the study explained that the average ability to understand mathematical concepts of students who use a realistic mathematical approach is higher than the average ability to understand mathematical concepts of students who use conventional learning. It can be seen from the average posttest score of students' mathematical problem-solving ability of 29.125 in the experimental class and 27.250 in the control class. However, the realistic mathematical approach model in the experimental class was significantly more successful in improving students' understanding of mathematical concept skills compared to conventional methods. Thus the learning of realistic mathematics influences the ability to understand the concepts of mathematical students $\left(t_{\text {count }}=3.91>t_{\text {table }}=2.13\right)$. The conclusion of this study is that there is a positive influence on realistic mathematical approaches to students' mathematical concept understanding abilities.
\end{abstract}

Keywords: Realistic Mathematics Approach, Understanding of Mathematical Concepts.

\begin{abstract}
Abstrak. Tujuan dari penelitian ini adalah untuk mengetahui pengaruh pembelajaran dengan menggunakan pendekatan matematika realistik terhadap kemampuan pemahaman konsep matematis siswa. Penelitian ini adalah jenis penelitian quasi eksperimen. Penelitian ini dilaksanakan di MTs Islamiyah Medan. Sampel penelitian ini berjumlah 50 siswa, 25 siswa kelas eksperimen dan 25 siswa kelas kontrol yang diperoleh dengan teknik cluster random sampling pada siswa kelas VII. Hasil penelitian menjelaskan bahwa rata-rata kemampuan pemahaman konsep matematik siswa yang menggunakan pendekatan matematika realistik lebih tinggi dari pada rata-rata kemampuan pemahaman konsep matematika siswa yang menggunakan pembelajaran konvensional. Terlihat dari nilai rata-rata postest kemampuan pemecahan masalah matematis siswa sebesar 29,125 pada kelas eksperimen dan sebesar 27,250 pada kelas kontrol. Namun model pendekatan matematika realistik pada kelas eksperimen secara signifikan lebih berhasil meningkatkan kemampuan pemahaman konsep matematis siswa dibandingkan dengan metode konvensional. Dengan demikian pembelajaran matematika realistik berpengaruh terhadap kemampuan pemahaman konsep matematikasiswa ( $\mathrm{t}_{\text {hitung }}=3,91$ $\left.>t_{\text {tabel }}=2,13\right)$. Kesimpulan penelitian ini adalah terdapat pengaruh positif pendekatan matematika realistik terhadap kemampuan pemahaman konsep matematis siswa.
\end{abstract}

Kata Kunci: Pendekatan Matematika Realistik, Pemahaman Konsep Matematis.

\section{PENDAHULUAN}

Dalam mengembangkan potensi dalam diri, setiap manusia membutuhkan pendidikan. Karena pendidikan merupakan faktor utama dalam membentuk pribadi manusia. Dalam perspektif individu, proses pendidikan menghasilkan perubahan tingkah laku anak didik melalui pembinaan atau bimbingan terhadap potensi (Syafaruddin dan Nurmawati; 2011). Dalam pendidikan tidak terlepas dari proses pembelajaran. Dalam proses pembelajaran guru dituntut untuk aktif, kreatif dan inovatif. Sehingga diharapkan dapat mengembangkan potensi peserta didik secara optimal. Salah satu pelajaran yang penting dalam menunjang peningkatan kualitas para peserta didik yaitu pelajaran 
matematika. Matematika merupakan pelajaran yang menuntut pola berfikir yang logis, sistematis dan terstruktur. Guru sebagai tenaga pendidik tetap harus berpikir keras bagaimana mengemas materi pelajaran matematika agar menjadi menarik dan mudah dipahami oleh siswa, sehingga gairah dan motivasi mereka untuk belajar matematika meningkat. Karena gairah dan motivasi yang kuat merupakan salah satu faktor pendorong keberhasilan pembelajaran.

Proses pembelajaran pada kurikulum 2013 yang termuat dalam draft pengembangan kurikulum 2013 lebih menekankan pada proses belajar yang berpusat pada siswa. Selain itu proses pembelajaran juga diharapkan mengacu pada pendekatan saintifik dimana siswa tidak lagi diberi tahu namun, mencari tahu sendiri melalui penemuan. Peserta didik harus dibekali bagaimana belajar itu yang sebenarnya. Oleh karenanya peserta didik harus dilatih menyelesaikan masalah.

Kegiatan proses belajar mengajar bertujuan untuk mencapai hasil yang optimal, hal ini dapat tercapai jika siswa sebagai subyek belajar terlibat aktif dalam proses belajar mengajar dan guru sebagai salah satu peran penting dalam proses belajar mengajar. Pada pembelajaran aktif siswa di tuntut untuk aktif berpartisipasi dalam kegiatan pembelajaran dan fungsi guru hanyalah menciptakan kondisi yang memungkinkan siswa untuk berkembang secara optimal. Kegiatan pembelajaran merupakan proses komunikasi dua arah yang dilakukan guru dan siswa. Dalam proses belajar mengajar aktivitas merupakan hal yang sangat perlu untuk diperhatikan. Artinya keaktifan dan kreativitas siswa selama proses pembelajaran merupakan aktivitas belajar, dalam proses belajar, kegiatan-kegiatan yang dilakukan siswa berpengaruh terhadap hasil belajarnya. Hal ini disebabkan karena pada prinsipnya belajar adalah berbuat (berbuat untuk mengubah tingkah laku artinya melakukan sesuatu kegiatan) tidak ada belajar kalau tidak ada aktivitas itulah sebabnya aktivitas merupakan prinsip yang sangat penting dalam interaksi belajar mengajar.

Slameto (2011), menyatakan bahwa dalam proses belajar mengajar, guru perlu menimbulkan aktivitas siswa dalam berfikir maupun berbuat. Penerimaan pembelajaran jika dengan aktivitas siswa sendiri, kesan itu tidak akan berlalu begitu saja, tetapi difikirkan, diolah kemudian dikeluarkan lagi dalam bentuk yang berbeda. Atau siswa akan bertanya, mengajukan pendapat menimbulkan diskusi dengan guru. Dalam berbuat siswa dapat menjalankan perinta, melaksanakan tugas, membuat grafik, diagram, intisari pelajaran yang disajikan oleh guru. Bila siswa menjadi partisipasi yang aktif, maka ia akan memliki ilmu/pengetahuan itu dengan baik.

Berdasarkan pendapat tersebut, pembelajaran matematika di kelas ditekankan pada keterkaitan antara konsep-konsep matematika dengan pengalaman anak sehari-hari. Selain itu, perlu menerapkan kembali konsep matematika yang telah dimiliki anak pada kehidupan sehari-hari atau pada bidang lain yang sangat penting dilakukan. Menerapkan matematika dalam kehidupan sehari-hari merupakan pembelajaran matematika realistik.

Namun, kenyataan saat ini menunjukkan bahwa pencapaian siswa pada pelajaran matematika tergolong rendah dan belum memenuhi harapan. Hal ini diindikasikan dengan rendahnya hasil belajar siswa begitu juga dengan kemampuan koneksi matematis siswa. Ini terlihat baik dari hasil ujian nasional maupun hasil-hasil penelitian menunjukkan bahwa penguasaan siswa terhadap matematika masih relatif rendah.

Rendahnya kemampuan siswa serta kesalahan siswa dalam menyelesaikan masalah matematika dapat kita ketahui dari beberapa hasil penelitian. Penelitian yang dilakukan oleh Nuroniah, dkk (2013) memperoleh hasil bahwa kecenderungan kesalahan yang dilakukan peserta didik hampir merata untuk setiap soal yang diberikan, dan kecenderungan kesalahan yang paling menonjol yaitu kesalahan data yang tidak tepat, prosedur tidak tepat dan hierarki keterampilan. Adapun penyebab kesalahan terjadi karena peserta didik belum memiliki keterampilan menyelesaikan masalah matematika, serta 
belum terlihatnya keterampilan manipulasi numerik sehingga memberikan kesimpulan bahwa kemampuan masalah peserta didik masih rendah.

Dari keterangan hasil penelitian di atas menunjukkan bahwa siswa masih banyak melakukan kesalahan dalam menyelesaikan soal-soal matematika. Kesalahan-kesalahan yang dilakukan siswa disebabkan karena siswa sulit memahami soal, belum terampil dalam memecahkan masalah dan siswa jarang diberikan soal berbentuk soal cerita yang mengarah pada kemampuan pemecahan masalah yang mengakibatkan siswa mengalami kesulitan dalam menyelesaikan soal-soal kemampuan pemecahan masalah. Sehingga dapat kita ambil kesimpulan bahwa kemampuan siswa dalam memahami konsep pelajaran masih rendah masih rendah.

Selain dari hasil penelitian tersebut peneliti juga melakukan observasi di MTs Islamiyah Medan. Berdasarkan hasil observasi pembelajaran matematika di kelas VII, pembelajaran pada umumnya di sekolah tersebut masih menggunakan metode ceramah dan wawancara dengan guru matematika disekolah tersebut, guru mengatakan bahwa pemberian tugas mandiri dan menggunakan kelompok diskusi, namun metode ini tidak dapat mengatasi masalah pemahaman konsep siswa. Meskipun sudah dilakukan berbagai cara untuk meningkatkan pemaham konsep siswa, seperti diadakannya remedial bagi siswa yang nilainya tidak mencapai standar ketuntasan dan memberi tugas pengembangan materi yang berupa soal. Tetapi belum bisa mengatasi masalah pemahaman konsep siswa. Rendahnya kemampuan pemahaman konsep matematika diantaranya: setiap guru memberi tugas banyak siswa menjawab salah, siswa tidak dapat menjelaskan kembali mengenai materi yang telah dipelajari, sebagian siswa tidak bisa menjawab soal yang bervariasi, kurang memahami materi yang diajarkan oleh guru.

Untuk memperkuat pernyataan bahwa kemampuan pemahaman konsep rendah maka diberikan tes kepada siswa. untuk mengukur pengetahuan awal siswa. Tes ini bertujuan untuk melihat sejauh mana pemahaman siswa dalam menyelesaikan soal tes. Dari tes yang diberikan diperoleh hasil bahwa dari 25 siswa terdapat 5 siswa yang menjawab benar, 12 siswa yang menjawab salah dan 8 siswa tidak menjawab, ini dapat dilihat dari hasil pengerjaan peserta didik ketika mengerjakan soal pemahaman konsep matematika yang menunjukkan kurangnya kemampuan siswa dalam memahami konsep materinya. Hasil yang diperoleh menunjukkan bahwa masih banyak siswa yang belum mampu memahami dan menyelesaikan soal dengan benar.

Proses pembelajaran pemecahan masalah tentu saja siswa dihadapkan pada masalahmasalah matematik. Proses pembelajarannya diawali dengan pengajuan masalah. Masalah tersebut disajikan berupa konteks masalah. Dengan adanya konteks yang diberikan kepada siswa nantinya akan mengajak siswa untuk berpikir membangun sendiri pengetahuannya untuk memecahkan masalah tersebut.

Dalam mengatasi masalah-masalah tersebut, perlu diterapkan suatu pendekatan pembelajaran matematika yang tidak hanya memberi pengetahuan guru kepada siswa. Akan tetapi, pembelajaran ini seharusnya juga memberi kesempatan siswa untuk mengembangkam ide-ide matematikanya dengan mengaitkan pengalaman kehidupan nyata siswa pada materi yang diajarkan. Pendekatan pembelajaran yang dianggap tepat adalah pendekatan pembelajaran matematika realistik yaitu pendekatan pembelajaran yang mengarah pada matematika dengan kehidupan sehari-hari.

Oleh karena itu, diperlukan suatu model pembelajaran yang dapat menumbuhkan rasa ingin tau dan rasa percaya diri agar siswa dapat menghasilkan pembelajaran yang aktif dan bermakna bagi siswa, salah satu model pembelajaran yang aktif dan mampu meningkatkan keinginan siswa untuk menjadi lebih baik kedepannya ialah strategi Pembelajaran Matematika Realistik. Model ini dikenalkan oleh Institut Freudental (1970) di Belanda, yang mengatakan bahwa matematika harus dikaitkan dengan realita dan matematika 
merupakan aktivitas manusia. Ini berarti matematika harus dekat dengan anak dan relevan dengan kehidupan sehari-hari.

Hal tersebut didasari oleh beberapa penelitian yang telah berhasil dilakukan, diantaranya adalah hasil penelitian yang dilakukan oleh Diyah (2007) dengan judul penelitian Keefektifan Pembelajaran Realistik (PMR) Pada Kemampuan Pemecahan Masalah Matematika Siswa Kelas VII SMP 41 Semarang. Diyah memusatkan penelitiannya terhadap kemampuan pemecahan masalah siswa. Hasil penelitian diyah membuktikan bahwa PMR atau RME dapat meningkatkan kemampuan pemecahan masalah siswa dengan rata-rata kemampuan pemecahahan masalah siswa dengan pembelajaran matematika realistik sebesar 72,62 sedangkan nilai rata-rata kemampuan pemecahan masalah siswa pada kelas konvensional sebesar 66,67 dan Rata-rata keaktifan siswa dalam penerapan kelima prinsip PMR sebesar 64,06\% sedangkan ratarata aktivitas guru sebesar $74,31 \%$.

Adapun hasil penelitian lain yang yang dilaksanakan oleh Soviawati (2011) Mengenai Pendekatan Matematika Realistik (PMR) untuk meningkatkan kemampuan berfikir siswa menunjukan bahwa dengan Pendekatan Matematika Realistik (PMR) siswa tidak hanya mudah menguasai konsep dan materi pembelajaran namun juga tidak cepat lupa dengan apa yang telah diperolehnya.

Dengan menumbuhkan aktivitas siswa dalam pembelajaran matematika maka pendekatan pembelajaran matematika realistik lebih tepat dengan meningkatkan pemahaman konsep matematis. Hal ini dikarenakan Pendekatan Matematika Realistik, memudahkan siswa dalam memahami materi dan memecahkan masalah karena siswa diberi waktu lebih banyak untuk berpikir, berdiskusi, menjawab soal dan saling membantu siswa lain.

\section{METODE}

Penelitian ini merupakan penelitian quasi experimental karena kondisi siswa tidak dapat dikontrol sepenuhnya seperti: persiapan siswa sebelum belajar di sekolah, les tambahan di luar jam sekolah, hubungan siswa dengan orang tua, hubungan siswa dengan lingkungannya dan lain sebagainya. Dalam melaksanakan penelitian ini melibatkan dua perlakuan yaitu kelas eksperimen yang diberi perlakuan pendekatan matematika realistik dan kelas kontrol yang diberi pembelajaran konvensional. Penelitian ini dilaksanakan di MTs Islamiyah Medan dengan populasi seluruh siswa kelas VII MTs Islamiyah Medan tahun ajaran 2018/2019 yang terbagi menjadi 2 kelas yaitu kelas VII-1 sampai dengan kelas VII-2 berjumlah 50 orang. Pengambilan sampel pada penelitian ini dilakukan teknik simple randaom sampling sehingga diperoleh kelas VII-1 (kelas eksperimen) dan VII-2 (kelas kontrol).

Tujuan dari penelitian ini adalah untuk mengetahui pengaruh pendekatan matematika realistic terhadap kemampuan pemahaman konsep matematis siswa sehingga untuk mengetahuinya diberikan soal tes kemampuan pemahaman konsep matematis dengan desain dalam penelitian ini adalah postes control group design. Instrumen yang digunakan dalam penelitian ini adalah soal tes kemampuan pemahaman konsep matematis siswa.

\section{HASIL DAN PEMBAHASAN}

Hasil penelitian menjelaskan bahwa rata-rata kemampuan pemahaman konsep matematik siswa yang menggunakan pendekatan matematika realistik lebih besar dari pada rata-rata kemampuan pemahaman konsep matematika siswa yang menggunakan pembelajaran konvensional. Terlihat dari nilai rata-rata posttest kemampuan pemecahan masalah matematis siswa sebesar 29,125 pada kelas eksperimen dan sebesar 27,250 pada kelas kontrol. Namun model pendekatan matematika realistik pada kelas eksperimen secara 
signifikan lebih berhasil meningkatkan kemampuan pemahaman konsep matematis siswa dibandingkan dengan metode konvensional pada kelas kontrol. Peningkatan dilihat dari hasil analisis skor gain, diketahui bahwa rata-rata gain kelas eksperimen berada dalam kategori sedang $(0,696)$ dan rata-rata gain kelas kontrol berada dalam kategori sedang namun lebih rendah dari kelas eksperimen $(0,615)$. Hasil diatas menandakan bahwa terjadi peningkatan kemampuan pemecahan masalah matematis kelas eksperimen lebih tinggi dari peningkatan kemampuan pemecahan masalah pada kelas kontrol.

Berdasarkan pengujian hipotesis menggunakan uji t pada taraf signifikansi $\alpha=0,05$ dan derajat kebebasan $(\mathrm{dk})=15,31$ diperoleh nilai $\mathrm{t}_{\text {hitung }}$ sebesar 3,91. Sedangkan dari hasil perhitungan didapat nilai $t_{\text {tabel }}=2,13$. Dari hasil perhitungan diperoleh rata-rata kemampuan pemahaman konsep matematik siswa yang menggunakan pembelajaran matematika Realistik (PMR) lebih besar daripada rata-rata kemampuan pemahaman konsep matematik siswa yang menggunakan pembelajaran konvensional. Sehingga dapat disimpulkan bahwa terdapat pengaruh positif model Pembelajaran Matematika Realistik (PMR) terhadap kemampuan pemahaman konsep matematika siswa.

Kemampuan pemahaman konsep matematik siswa yang diterapkan PMR (Pembelajaran Matematika Realistik) memiliki pengaruh positif dibandingkan dengan siswa yang diterapkan model pembelajaran konvensional. Siswa pada kelas eksperimen dapat menuliskan rumus dan memahami materi Aritmetika Sosial. Pada pembelajaran PMR (Pembelajaran Matematika Realistik), siswa dilatih untuk mengkonsep tiap siswa secara berpasangan terkait dengan permasalahan matematik yang berkaitan dengan untung dan rugi. Kemudian pasangan merefleksikan apa yang telah ditulis oleh temannya. Pada proses ini, peneliti menilai kedalaman pemahaman atau ide yang dikemukanan siswa.

Siswa secara bergantian bertukar peran sebagai penyampai ide dan penerima ide yang diberikan temannya. Setelah keduanya selesai menjelaskan (secara tertulis dan lisan) konsep yang terkait dengan apa yang ditulis temannya, merekan mendiskusikan atau menyamakan konsep yang ia dan pasangannya tulis. Proses diskusi yang dilakukan oleh siswa, dipantau dan dimonitori oleh peneliti sehingga peneliti dapat memberikan motivasi dan mengarahkan siswa jika terdapat siswa yang tidak menanggapi ide atau menilai yang dikemukakan temannya secara tertulis. Siswa pada kelas eksperimen memiliki keunggulan untuk memberikan gagasan yang beragam dari materi yang diberikan, sedangkan siswa pada kelas kontrol yang diajarkan dengan pembelajaran konvensional kurang mampu merefleksikan soal terkait materi yang memahami ritmetika sosial sehingga mereka kesulitandalam membuat cerita maupun dalam memberikan penjelasan dengan bahasa sendiri terkait permasalahan matematik.

Hal ini dikarenakan dalam proses pembelajaran guru hanya menerangkan materi dan melakukan tanya jawab setelah materi selesai diterangkan. Sanjaya (2006) menyatakan bahwa pada pembelajaran konvensional siswa ditempatkan sebagai obyek belajar yang berperan sebagai penerima informasi secara pasif. Jadi pada umumnya penyampaian pelajaran menggunakan metode ceramah, tanya jawab dan penugasan. Menurut Djafar (2001) pembelajaran konvensional dilakukan dengan satu arah. Dalam pembelajaran ini peserta didik sekaligus mengerjakan dua kegiatan yaitu mendengarkan dan mencatat. Sehingga menyebabkan siswa cenderung pasif dan tidak memiliki banyak kesempatan untuk mengkomunikasikan gagasan ataupun ide mereka. Pada akhirnya siswa hanya menghafal materi yang diberiskan sehingga siswa kesulitan untuk menyelesaikan soal komunikasi matematik maupun permasalahn kehidupan sehari-hari yang berkaitan dengan keliling dan luas segiempat.

Mencermati hasil penelitian yang telah dikemukakan diatas, menunjukkan bahwa pembelajaran dengan pendekatan matematika realistik lebih baik dalam meningkatkan kemampuan pemahaman konsep matematis siswa dibandingkan dengan pembelajaran 
konvensional. Karakteristik pembelajaran dari kedua pendekatan tersebut memperlihatkan bahwa, kewajaran terjadinya perbedaan terhadap kemampuan siswa setelah mengikuti proses pembelajarannya. Secara teoritis, pembelajaran dengan pendekatan matematika realistik memiliki beberapa keunggulan jika dibandingkan dengan pembelajaran dengan konvensional, yang apabila keunggulan-keunggulan ini dimaksimalkan dalam pelaksanaan di kelas sangat memungkinkan proses pembelajaran menjadi lebih baik. Keunggulan tersebut dapat dilihat melalui perbedaan pandangan terhadap karakteristik kedua pembelajaran antara lain faktor guru.

Dalam pendekatan matematika realistik guru berperan sebagai fasilitator belajar. Implikasi dari pandangan ini adalah keharusan bagi guru untuk memfasilitasi dan mendorong siswa untuk terlibat aktif dalam proses pembelajaran. Siswa didorong untuk mengkontruksi pengetahuan bagi dirinya dan bekerja sama antar teman dalam kelompok. Untuk keperluan tersebut maka siswa perlu mendapat keleluasaan dalam mengekspresikan jalan pemikiran dalam menyelesaikan masalah yang dihadapi bersama teman kelompoknya. Untuk mewujudkan situasi dan kondisi belajar yang demikian maka dalam mengelolah pembelajaran guru perlu mendorong siswa untuk berani mencoba kemungkinan cara memahami dan menyelesaikan masalah. Siswa diberikan kesempatan untuk membuat suatu permasalahan, menyelesaikannya dan berbagai pengetahuan dengan teman kelompoknya. Pengelolaan guru akan sangat dibutuhkan karena guru akan menjadi fasilitator dan mediator pelaksanaan pembelajaran.

Sebaliknya dalam pembelajaran konvensional, guru menjadi pusat pembelajaran. Dalam pembelajaran ini lebih menekankan guru mendemonstrasikan materi, melatih menyelesaikan soal, menanyakan rumus-rumus, membahas latihan dan siswa dianggap berhasil apabila menyelesaikan latihan dengan langkah-langkah yang telah diajarkan guru. Hal ini mengakibatkan terjadinya penghafalan konsep atau prosedur dan komunikasi matematis siswa yang rendah serta siswa cepat untuk menyerah jika diberikan masalah yang lebih kompleks. Hal itulah yang mengakibatkan pemelajaran dengan pendekatan matematika realistik lebih baik daripada metode konvensional.

\section{KESIMPULAN}

Berdasarkan hasil penelitian dan pembahasan dapat disimpulkan bahwa pemahaman konsep matematika dengan menggunakan pembelajaran Konvensional tidak berpengaruh pada siswa kelas VII MTs Islamiyah Medan. Akan tetapi, pemahaman konsep matematis siswa yang mengikuti pembelajaran dengan Pendekatan Matematika Realistik (PMR) lebih baik dari pada pemahaman konsep matematis siswa yang tidak mengikuti pembelajaran dengan Pendekatan Matematika Realistik (PMR).

Berdasarkan hasil penelitian pada pembelajaran matematika dengan menggunakan pendekatan matematika realistik guna meningkatkan kemampuan pemahaman konsep matematis siswa, maka peneliti memberikan saran untuk pihak-pihak yang terkaid antara lain sebagai berikut:

1. Pembelajaran dengan Pendekatan Matematika Realistik (PMR) sebaiknya digunakan sebagai salah satu opsi dalam pembelajaran matematika guna untuk membantu siswa dalam mengembangkan pemahaman konsep matematisnya.

2. Bagi peneliti lain yang ingin mengembangkan penelitian lanjutan mengenai pembelajaran dengan Pendekatan Matematika Realistik (PMR) hendaknya melakukan pengkajian lebih mendalam, seperti memperhatikan materi yang akan diajarkan sebab pembelajaran dengan Pendekatan Matematika Realistik (PMR) sulit untuk diimplementasikan dalam beberapa materi matematika. Selain itu, dapat pula digunakan untuk menambahkan referensi tentang efektivitas pembelajaran dengan 
Pendekatan Matematika Realistik (PMR) ditinjau dari pemahaman konsep matematis siswa.

\section{DAFTAR PUSTAKA}

Darto. 2008. Meningkatkan Kemampuan Komunikasi dan Pemecahan Masalah Matematis Siswa Melalui Pendekatan Realistic Mathematics Education Di SMP Negeri 3 Pangkalan Kuras, Tesis.Pekanbaru: Universitas Riau.

Departemen Pendidikan Nasional.2006. Model Penilaian Kelas, Badan Standar Nasional Pendidikan, Jakarta: Depdiknas.

Diyah.2007.Keefektifan Pembelajaran Matematika Realistik (PMR) pada Kemampuan Pemecahan Masalah Matematika Siswa Kelas VII SMP. Skripsi FMIPA UNNES: Semarang.

Gravemeijer.1994. Developing Realistic Mathematics Education .Utrecht: Freundenthal Institute.

Hudojo, H. 1979. Pengembangan Kurikulum Matematika dan Pelaksanaannya Di Depan Kelas. Surabaya: Usaha Nasional.

Kilpatrick, J \& Findel, D. (Eds). 2001. Adding It Up: Helping Children Learn Mathematics. Washington: Nasional Academy Press.

Made Suarjana, Menumbuh Kembangkan Kemampuan Pemecahan Masalah, Penalaran, dan komunikasi Matematik Melalui Pembelajaran Matematika Realistik, undiksha.ac.id/images/img_item/904.doc, $h$. 941, diakses tanggal 3 Desember 2017 jam 11.13

Mawaddah, S. \& Anisah, H. 2015. Kemampuan Pemecahan Masalah Matematis Siswa Pada Pembelajaran Matematika dengan menggunakan Model pembelajaran Generatif (Generative Learning) Di SMP. EDU-MAT. Jurnal pendidikan Matematika. 3 (2) 167.

Nation Council of Teachers of Mathematics (NCTM). 2000. Principles and Standards for School Mathematics. United States of America: The National Council of Teacher of Mathematics Inc.

Sanjaya, W. 2006. Strategi Pembelajaran Berorientasi Standar Proses pendidikan. Jakarta: Kencana Prenada Group

Slameto. 2011. Belajar dan Faktor-faktor yang Mempengaruhinya, Jakarta: Rineka Cipta. Sugiono. 2010. Metode Penelitian Pendidikan. Bandung, Alfabeta. Bandung: Tarsito, h. 156

Syafaruddin \& Nurmawati. 2011. Pengelolaan Pendidikan Mengembangkan Keterampilan Manajemen Pendidikan Menuju Sekolah Efektif. Medan: Perdana Publishing.

Van den Hauvel-Panhuizen, M. 1985. Asswsmen and Realistic Mathematics Education.

Virlianti, Y. 2002. Analisis Pemahaman Konsep Siswa dalam Memecahkan Masalah Konstektual pada Pembelajaran Matematika Melalui Pendekatan Realistik. Skripsi Jurusan Pendidikan Matematika FPMIPA UPI (Tidak dipublikasikan), h.6

Winarsih. 2015. Penerapan Model STAD Untuk Meningkatkan Keaktifan Siswa Pada Materi Segitiga. Jurnal Dinamika. 5(3): 84. 